\title{
Soybean Response to Flooded Soil Conditions and the Association with Soilborne Plant Pathogenic Genera
}

\author{
M. T. Kirkpatrick, J. C. Rupe, and C. S. Rothrock, Department of Plant Pathology, University of Arkansas, \\ Fayetteville 72701
}

\begin{abstract}
Kirkpatrick, M. T., Rupe, J. C., and Rothrock, C. S. 2006. Soybean response to flooded soil conditions and the association with soilborne plant pathogenic genera. Plant Dis. 90:592-596.

The role of soilborne pathogens in flood damage on soybeans, Glycine max, was examined using six genotypes representing a reputed range of flood tolerances. Genotypes were planted in single-row plots from 1996 to 1998 with flood treatments of no flood, flood at emergence (3-day duration), or flood at the fourth leaf node growth stage (7-day duration). Three or four days after removing each flood treatment, plant stands were estimated and 15 plants were collected from each plot, weighed, and rated for root discoloration. Roots were assayed for the presence of fungi and other filamentous eukaryotic organisms. Plant stands were reduced by flooding at emergence compared with the nonflooded control. Flooding at both growth stages caused significant increases in root discoloration compared with nonflooded soybeans. Plant weights were reduced in 2 of 3 years for flooding at emergence. Pythium was the only genus of filamentous organisms whose isolation frequency increased with flooding. Of the 60 Pythium isolates evaluated representing the different cultural groups based on appearance and growth rate on potato dextrose agar, cornmeal agar, and V8 agar, $47 \%$ were moderately to highly virulent on soybean. Pythium spp. isolated from soybean included the pathogenic species P. ultimum, P. aphanidermatum, P. irregulare, and $P$. vexans and Group HS. Nonpathogenic P. oligandrum also was isolated from soybean.
\end{abstract}

Arkansas soybean production occurs primarily on alluvial soils with poor surface and internal drainage. As a result, fields are prone to prolonged flooding that can harm plants at any growth stage. Greatest stand losses occur during the early vegetative stages. Flooding of soybean fields in the midwestern states also has resulted in extensive crop damage (27). These losses have increased awareness of flood damage on soybean (Glycine max (L.) Merrill) and focused the attention of researchers on developing flood tolerant genotypes. Flood tolerance can be defined as genotypes that yield well following flooding relative to current, flood-sensitive genotypes (25).

Plants species vary in their response to flooding, but soybeans are generally sensitive to it $(18,20,22)$. Flooding soybeans has been reported to significantly reduce seed

Corresponding author: J. C. Rupe

E-mail: jrupe@uark.edu

Published with the approval of the director of the Arkansas Agricultural Experiment Station, Fayetteville.

Current address of M. T. Kirkpatrick: Department of Plant and Soil Sciences, Mississippi State University, Mississippi State 39762.

Accepted for publication 14 December 2005.

DOI: 10.1094/PD-90-0592

(C) 2006 The American Phytopathological Society yield compared with nonflooded soybeans $(11,22)$. Flood damage in soybean may be the result of death of root cortical tissue, reduced vigor, and wilting as a result of hypoxic conditions (16). Lack of oxygen diffusion and increased $\mathrm{CO}_{2}$ around the root system also can inhibit nitrogen fixation (2). Flooding has been shown to decrease respiration, causing an increase in membrane permeability, which can result in plant cell death $(1,7)$. This increase in membrane permeability results in "leakiness" that increases loss of nutrients from the tissue (9)

Once parts of the root system are weakened, more damage can occur from facultative parasites favored by flooded environments. Soilborne pathogens that are commonly recovered from soybean roots include Pythium spp., Phytophthora sojae, Fusarium spp., and Rhizoctonia solani $(13,32)$. Some of these pathogens have been shown to cause increased plant damage under flooded soil conditions (3$5,12,19,28,30)$. Flooding may favor these pathogens because of the expansion of the plant rhizosphere. Exudates act as chemoattractants for pathogens, including zoospores of Pythium and Phytophthora spp. $(15,21)$. It is unclear if flood damage to soybean is a result solely of the physical environment or if soilborne plant pathogens contribute to the damage that occurs when soybeans are flooded.

The objectives of this research were to (i) determine the effects of flooding on soybean growth and development, (ii) identify genera of filamentous plant pathogens recovered from soybean roots following flooding, and (iii) identify Pythium spp. associated with soybeans.

\section{MATERIALS AND METHODS}

Field study. Field studies were conducted at the Pine Tree Station near Colt, $\mathrm{AR}$, on a Calloway silt loam (Glossaquic fragiudalf) in 1996, 1997, and 1998. Each year, the experiment was located in a field that had been cropped to rice the previous year. Experimental areas to be flooded were surrounded with a 40-cm-high earthen levee formed with a levee plow (Rome Plow Co., Cedartown, GA). Flood treatments were applied to a depth of $3 \mathrm{~cm}$ at soybean emergence (VE) and at the fourth leaf node(V4) growth stages (8), with flood durations of 3 and 7 days, respectively. Flooding was extended for the V4 growth stage because previous studies had shown that a flood response at this growth stage required a flood duration of 4 days or longer (22). Six soybean genotypes representing a range of reputed flood sensitivities were tested each year: flood tolerant genotypes Hartz 5164, Riverside RVS-499, and TB881266; flood sensitive genotypes Crowley and Northrup King NK S59-60; and Asgrow 4715, of unknown flood reaction. Additional genotypes were planted each year, but were excluded from analysis because they were not planted in all years. The genotypes were planted in single-row plots, $6 \mathrm{~m}$ long and $76 \mathrm{~cm}$ apart, on 20 June 1996, 5 June 1997, and 18 May 1998. Experiments were designed each year as a split plot with flooding as the main plot and genotype as the split plot. Treatments for all experiments were replicated three times.

Four days (1996) or 3 days (1997 and 1998) after the removal of the flood, plant stand was estimated using a 0 to 5 scale with $0=$ none, $1=1$ to $20 \%, 2=21$ to $40 \%, 3=41$ to $60 \%, 4=61$ to $80 \%$, and 5 $=81$ to $100 \%$ of maximum possible stand. Ratings were converted to the midpoint percentages before analysis. At the same time, 15 plants were dug from the ends of each plot using a spade, and the loose soil was removed from the roots by gentle shaking. The sampled plants from each plot were placed into plastic bags on ice for transporting to the laboratory, and stored at $4{ }^{\circ} \mathrm{C}$ until processed. All plants were processed within a week of collec- 
tion. Plants were rinsed in running tap water, blotted dry, and weighed. The roots were cut from the plant tops $1 \mathrm{~cm}$ above the soil line and rinsed in running tap water for $20 \mathrm{~min}$, surface-disinfested in $0.5 \%$ sodium hypochlorite solution for $90 \mathrm{~s}$, and blotted dry with a sterile paper towel. The roots were rated visually for discoloration on a scale from 0 to 5 with $0=$ no discoloration, $1=1$ to $10 \%, 2=11$ to $25 \%, 3=$ 26 to $50 \%, 4=51$ to $75 \%$, and $5=76$ to $100 \%$ discoloration of the root system. In 1997, data on root discoloration were lost due to equipment failure. Ratings for root discoloration were converted to midpoint percentages before analysis.

After rating, organisms were isolated from the root systems by placing the roots on $1.5 \%$ water agar containing rifampicin (10 mg/liter), ampicillin (0.25 g/liter), and the miticide fenpropathrin, $0.14 \mathrm{mg}$ a.i./liter $(0.5 \mu \mathrm{l} /$ liter Danitol $2.4 \mathrm{EC}$, Valent U.S.A. Corporation, Walnut Creek, CA) in 9-cm plastic petri dishes. The entire root system of each seedling was placed in one dish. The roots were incubated at room temperature for 5 days. Colonies growing from the roots were transferred to potato dextrose agar (PDA) (Difco Laboratories, Detroit, MI) containing the same concentrations of antibiotics and miticide as the water agar. Multiple isolates were collected from most root systems. After 5 to 7 days, isolates on PDA were grouped by cultural appearance and identified to genus based on cultural morphology. One-tenth of the isolates of all pathogenic genera recovered from soybean roots were systematically selected and stored on cornmeal agar (17 $\mathrm{g}$ of CMA [Difco], $3 \mathrm{~g}$ of agar, and 1 liter of water) in sterile water vials $(3.7 \mathrm{ml})$. Identification to species and pathogenicity tests were conducted only on Pythium spp. because of the increase in percent recovery of this group of organisms from soybean roots under flooded field conditions over all years compared with nonflooded conditions.

Statistics. Statistical analyses were conducted using Proc GLM of SAS (SAS Institute, Cary, NC). Data were combined for the six genotypes sampled over 3 years, but for only 2 years for the root discoloration ratings. The analysis was conducted as a split-split plot with year as the main factor, flood treatment as the split factor, and genotype as the split-split factor. Separate analyses were conducted for the effects of flooding at emergence and at V4 on stand, root discoloration, average plant weight, and isolation frequency. Least significant differences were calculated for the significant main effects and interaction means using the guidelines provided by Little and Hills (14).

Pythium identification. A total of 212 Pythium isolates were transferred to three different media (CMA, PDA, or V8 agar). Radial growth was determined at 24, 48, and $72 \mathrm{~h}$ after transfer. The isolates were grouped according to their radial growth rate and cultural appearance on the three media. Approximately one-fourth of the isolates were arbitrarily selected from each group for identification to species. Identification was based on the size and shape of the oogonia and antheridia, and on sporangial formation and production of zoospores using the keys of Van der Plaats-Niterink (24) and Waterhouse (26). Sexual structures and zoospore production and release were observed by placing pieces of media containing hyphae of the isolate in a petri dish containing sterile water and wheat leaves that had been autoclaved in water twice for $30 \mathrm{~min}$ at a $24-\mathrm{h}$ interval. The water was decanted $48 \mathrm{~h}$ after addition of the isolate and flooded with cool water $\left(15^{\circ} \mathrm{C}\right)$. The isolates were examined starting at $30 \mathrm{~min}$ after flooding to observe zoospore production and release. Other methods of identification included growth on CMA amended with $\beta$-sitosterol (20 mg in $5 \mathrm{ml}$ of $100 \%$ ethanol per liter) or freshly ground cornmeal medium. The remaining isolates within each group were examined to confirm that they showed the same characteristics for the species.

Pathogenicity experiment. Sixty $P y$ thium isolates were arbitrarily selected from the groups differentiated by growth on the three media and were tested for pathogenicity. Inoculum of each isolate was produced in a sand-cornmeal medium consisting of $100 \mathrm{ml}$ of sand, $5.6 \mathrm{ml}$ of finely ground cornmeal, and $40 \mathrm{ml}$ of deionized water in 250-ml Erlenmeyer flasks. The flasks were autoclaved for $40 \mathrm{~min}$ and then reautoclaved for another $40 \mathrm{~min} 24 \mathrm{~h}$ later. Six $1-\mathrm{cm}^{2}$ pieces of medium from 3 day-old cultures of each isolate grown on CMA were transferred to separate flasks containing the sand-cornmeal mixture and incubated at room temperature for 9 days. The flasks were shaken every other day to ensure even distribution of hyphae throughout the medium. Styrofoam bowls (10 $\mathrm{cm}$ diameter $\times 7 \mathrm{~cm}$ deep) with holes punched in the bottom were filled to within $3 \mathrm{~cm}$ of the top with vermiculite. The vermiculite was then covered with 15 $\mathrm{ml}$ of the sand-cornmeal inoculum (2-mm layer), which was then covered with a 1.5$\mathrm{cm}$ layer of vermiculite. Five soybean seed of the genotype Hutcheson were placed onto the vermiculite and covered with another $1.5 \mathrm{~cm}$ of vermiculite. The bowls were placed into plastic trays filled to a depth of $2 \mathrm{~cm}$ with water. The trays were placed in a greenhouse for 10 days at a temperature range of 24 to $29^{\circ} \mathrm{C}$, and the water in the trays was replenished daily. The treatments were arranged in a randomized complete block design with three replications. Three controls were included in each experiment: a pathogenic isolate of $P$. ultimum recovered from cotton seedlings; an isolate of the nonpathogenic species, $P$. oligandrum, recovered from soybean; and a noninfested treatment. Ten days after seeding, each plant was rated on a 0 to 7 scale with $0=$ healthy, $1=1$ to $10 \%, 2=11$ to $25 \%, 3=26$ to $50 \%, 4=51$ to $75 \%$, and $5=76$ to $100 \%$ root discoloration. A rating of 6 was assigned to plants that germinated but were killed before emergence, and a rating of 7 was assigned to seeds that died before germination. The ratings of the five plants were averaged for each bowl and used for statistical analysis. The soybeans that had emerged by day 10 were weighed, and an average plant weight was determined. An average disease rating of 5 to 7 was designated as a highly virulent reaction, 4.0 to 4.9 moderately virulent, 3.0 to 3.9 weakly virulent, and 0 to 2.9 as avirulent. Roots of arbitrarily selected seedlings were assayed to determine if the isolate recovered was the isolate used to inoculate the plant.

\section{RESULTS}

Field study. Flooding at emergence had a significant effect on plant stand (Table 1). Significantly lower plant stands occurred in the flooded at emergence treatments compared with the nonflooded treatments over years and genotypes (32.1 and $82.2 \%$, respectively). There were significant flood by year interactions for plant stand and plant weight and a flood by genotype by year interaction for root discoloration (Table 1). The flood by year interaction observed for plant stand was

Table 1. Analysis of variance $P$ values for the effects of flooding at emergence ${ }^{\mathrm{a}}$ and host genotype ${ }^{\mathrm{b}}$ on plant stand and weight ${ }^{\mathrm{c}}$ and on root discoloration ${ }^{\mathrm{d}}$ of soybean over 3 years

\begin{tabular}{lrcccc}
\hline Source of variation & df & $\begin{array}{c}\text { Plant } \\
\text { stand (\%) }\end{array}$ & $\begin{array}{c}\text { Plant } \\
\text { weight }(\mathbf{g})\end{array}$ & df $^{\mathbf{d}}$ & $\begin{array}{c}\text { Root } \\
\text { rating (\%) }\end{array}$ \\
\hline Year & 2 & 0.0102 & 0.0001 & 1 & 0.2633 \\
Flood & 1 & 0.0381 & 0.2115 & 1 & 0.0221 \\
Flood $\times$ year & 2 & 0.0096 & 0.0001 & 1 & 0.5208 \\
Genotype & 5 & 0.1627 & 0.0543 & 5 & 0.4748 \\
Genotype $\times$ year & 10 & 0.0969 & 0.0870 & 5 & 0.7257 \\
Flood $\times$ genotype & 5 & 0.4692 & 0.2922 & 5 & 0.6403 \\
Flood $\times$ genotype $\times$ year & 10 & 0.9158 & 0.5944 & 5 & 0.0105 \\
\hline
\end{tabular}

${ }^{a}$ Plots were flooded for 3 days beginning at plant emergence.

${ }^{\mathrm{b}}$ Hartz 5164, Crowley, Asgrow A4715, NK S59-60, RVS-499, and TB881266.

${ }^{c}$ Plants were sampled 4 days (1996) or 3 days (1997 and 1998) after removal of the flood. Plant stand was estimated as percentage of maximum stand in the nonflooded plots. Plant weights and root ratings were based on 15 plants per plot.

${ }^{d}$ Root rating (percent root discoloration) for the years 1996 and 1998 only. 
due to a lower plant stand in the flood treatment in $1998(10.6 \%)$ compared with the flood treatments in 1996 and 1997 (40.6 and 45.6\%, respectively). In 1998, a $4.1-\mathrm{cm}$ rainfall occurred just after the removal of the flood at emergence treatment, prolonging the duration of the flood by 2 days. Plants flooded at emergence had significantly lower plant weights compared with nonflooded treatments in 1997 and 1998 (Table 2). The significant flood by genotype by year interaction observed for root discoloration ratings was due to significantly greater root discoloration for the genotype Crowley in 1996 in the nonflooded treatment $(38.5 \%)$ compared with the other genotypes (range 10.5 to $19.4 \%$ ) (Table 1). Roots of plants flooded at emergence had significantly greater root discoloration compared with the nonflooded treatment (75.7 and $20.0 \%$, respectively).

Flooding at the V4 growth stage did not significantly affect plant stand (Table 3). There was a significant flood by genotype by year interaction for plant weight, and a flood by genotype interaction for root discoloration (Table 3). Flooding caused significantly lower plant weights in 1997 for the genotypes Asgrow 4715, Crowley, NK S59-60, and RVS 499 compared with the nonflooded treatment (Table 4). In 1996 and 1998, there were no significant differences in plant weights between flooded and nonflooded treatments. Plant weights were greatest in $1997(8.9 \mathrm{~g})$, followed by 1998 (5.4 g) and 1996 (1.3 g). Root discoloration was significantly greater in the flooded $(65.2 \%)$ than in the nonflooded treatment $(23.0 \%)$. The significant flood by genotype interaction observed for root discoloration with the six genotypes was due to significantly greater root discoloration in the nonflooded treatment for Asgrow $4715(28.5 \%)$ compared with nonflooded treatments of RVS 499 and TB881266 (18.4 and 17.8\%, respectively). Root discoloration was significantly higher in $1997(51.5 \%)$ than in 1996 and 1998 (43.4 and $37.4 \%$, respectively).

Table 2. Effect of flooding soybean at emergence $^{\mathrm{a}}$ on plant fresh weight over 3 years

\begin{tabular}{llll}
\hline & \multicolumn{3}{c}{ Plant weight $(\mathbf{g})^{\mathbf{b}}$} \\
\cline { 2 - 4 } Flood & $\mathbf{1 9 9 6}$ & $\mathbf{1 9 9 7}$ & $\mathbf{1 9 9 8}$ \\
\hline No flood & 0.43 & 1.76 & 1.69 \\
Flood & 0.35 & 1.58 & 1.10 \\
LSD $=0.09^{\mathrm{c}}$ & & & \\
LSD $=0.25^{\mathrm{d}}$ & & \\
\hline a Plots were flooded for 3 & days beginning at \\
plant emergence. \\
b Values are the means of six genotypes: Hartz \\
5164, Crowley, Asgrow A4715, NK S59-60, \\
RVS-499, and TB881266 sampled 4 days \\
(1996) or 3 days (1997 and 1998) after re- \\
moval of the flood. Plant weights were based \\
on 15 plants per plot. \\
c Least significant difference (LSD) to compare \\
flood treatments within a year $(P=0.05)$. \\
d LSD to compare flood treatments in different \\
years $(P=0.05)$.
\end{tabular}

Isolation. The plant pathogenic genera isolated from soybean roots were Pythium spp., Fusarium spp., R. solani, binucleate Rhizoctonia spp., Macrophomina phaseolina, and Gaeumannomyces graminis. Phytophthora sojae was not recovered from soybean roots. Comparison of the recovery of $M$. phaseolina from the roots of the six genotypes sampled after each flood treatment in the 3 years of the study resulted in a significant genotype by year interaction with flooding at emergence, and a flood by year interaction with flooding at V4 (Table 5). A significant flood by year interaction occurred for the recovery of Pythium spp. and Fusarium spp. when flooded either at emergence or V4. Compared with the nonflood treatment, recovery of $M$. phaseolina was numerically lower for both flood treatments, but was significantly lower only from plants flooded at the V4 growth stage (Table 6). The flood by year interaction was a result of the recovery of $M$. phaseolina being significantly greater for the genotype
Crowley following the flood at emergence (25.5\%) than the other cultivars (0 to $11.1 \%$ ) in 1998, but not in 1996 and 1997. Among the nonflooded treatments at V4, recovery of $M$. phaseolina was significantly greater in 1996 and 1997 than in 1998.

Isolation of Pythium spp. was significantly increased by flooding at emergence in 1998 and for all 3 years at V4. Recovery of Pythium spp. from plants was significantly greater in 1998 than in 1996 or 1997 for flooding at emergence and 1998 than in 1997 for flooding at V4. Recovery of Fusarium spp. was significantly lower in flooded than in nonflooded treatments for flooding at emergence in 1998, and the V4 flood in 1996 and 1998. R. solani, $G$. graminis, and binucleate Rhizoctonia spp. were recovered at low percentages (7.7, 2.2 , and $1.6 \%$, respectively, over all experiments). $R$. solani was lower after flooding at emergence than the nonflooded treatment, 1.0 and $2.5 \%$, respectively $(P=$ 0.0229).

Table 3. Analysis of variance $P$ values for the effects of flooding at the $\mathrm{V} 4^{\mathrm{a}}$ growth stage and host genotype $^{\mathrm{b}}$ on stand, plant weight ${ }^{\mathrm{c}}$, and root discoloration ${ }^{\mathrm{d}}$ of soybean over 3 years

\begin{tabular}{lrcccc}
\hline Source of variation & df & $\begin{array}{c}\text { Stand } \\
(\%)\end{array}$ & $\begin{array}{c}\text { Plant } \\
\text { weight }(\mathbf{g})\end{array}$ & $\mathbf{d f}^{\mathbf{d}}$ & $\begin{array}{c}\text { Root rating } \\
(\boldsymbol{\%})\end{array}$ \\
\hline Year & 2 & 0.0525 & 0.0001 & 1 & 0.0073 \\
Flood & 1 & 0.3440 & 0.4416 & 1 & 0.0093 \\
Flood $\times$ year & 2 & 0.4169 & 0.0553 & 1 & 0.2140 \\
Genotype & 5 & 0.7429 & 0.1488 & 5 & 0.6038 \\
Genotype $\times$ year & 10 & 0.4020 & 0.4854 & 5 & 0.1362 \\
Flood $\times$ genotype & 5 & 0.9183 & 0.2797 & 5 & 0.0239 \\
Flood $\times$ genotype $\times$ year & 10 & 0.6237 & 0.0025 & 5 & 0.3912 \\
\hline
\end{tabular}

${ }^{\text {a }}$ Plots were flooded for 7 days when the plants reached the fourth leaf node growth stage (V4) (8).

${ }^{\mathrm{b}}$ Hartz 5164, Crowley, Asgrow A4715, NK S59-60, RVS-499, and TB881266.

${ }^{\text {c }}$ Plants were sampled 4 days (1996) or 3 days (1997 and 1998) after removal of the flood. Plant stand was estimated as percentage of maximum stand in the nonflooded plots. Plant weights and root ratings were based on 15 plants per plot.

${ }^{\mathrm{d}}$ Root discoloration for the years 1996 and 1998.

Table 4. Effect of flooding at $\mathrm{V} 4^{\mathrm{a}}$ growth stage on plant fresh weight ${ }^{\mathrm{b}}$ for six soybean genotypes over 3 years

\begin{tabular}{lcccc}
\hline & & \multicolumn{3}{c}{ Plant weight (g) } \\
\cline { 2 - 5 } Genotype & Flood & $\mathbf{1 9 9 6}$ & $\mathbf{1 9 9 7}$ & $\mathbf{1 9 9 8}$ \\
\hline Asgrow A4715 & - & 1.5 & 11.8 & 5.1 \\
& + & 1.6 & 6.8 & 5.6 \\
Crowley & - & 1.1 & 8.8 & 4.6 \\
& + & 1.3 & 6.1 & 4.8 \\
Hartz 5164 & - & 1.0 & 8.3 & 6.0 \\
NK S59-60 & + & 1.3 & 8.5 & 5.4 \\
& - & 1.2 & 9.6 & 5.1 \\
RVS 499 & + & 1.3 & 6.7 & 4.7 \\
& - & 1.2 & 1.8 & 5.7 \\
TB881266 & + & 1.1 & 9.0 & 6.1 \\
& - & 1.3 & 7.5 & 6.2 \\
LSD $=1.7^{\mathrm{c}}$ & + & & & 5.2 \\
LSD $=2.5^{\mathrm{d}}$ & & & & \\
LSD $=3.2^{\mathrm{e}}$ & & & & \\
\hline
\end{tabular}

a Plots were flooded for 7 days when plants reached the fourth leaf node growth stage (V4) (8).

${ }^{b}$ Plants were sampled 4 days (1996) or 3 days (1997 and 1998) after removal of the flood. Plant weights were based on 15 plants per plot.

${ }^{\mathrm{c}}$ Least significant difference (LSD) to compare genotypes within the same flood and year treatment $(P$ $=0.05$ ).

${ }^{\mathrm{d}}$ LSD to compare flood treatments in the same year $(P=0.05)$.

${ }^{\mathrm{e}} \mathrm{LSD}$ to compare means in different years $(P=0.05)$. 
Identification and pathogenicity. Grouping of 208 selected isolates of $P y$ thium spp. on the three media resulted in 15 distinct groups. Of the 208 isolates, 152 were placed in five major groups (A-E), 52 were placed in 10 minor groups (F-O), and 8 isolates were not grouped. Pathogenicity tests of isolates arbitrarily selected from these groups demonstrated that $47 \%$ of the isolates tested were pathogenic to soybean and were moderately or highly aggressive based on plant emergence and root discoloration. Plant weights resulted in similar trends as root discoloration, but were not as discriminating. For the three pathogenicity experiments, disease ratings ranged from 2.0 to $6.5,2.9$ to $5.1,1.9$ to 4.5 , and plant weights from 0.7 to $1.5 \mathrm{~g}$, 0.9 to $1.3 \mathrm{~g}$, and 1.5 to $2.1 \mathrm{~g}$ for the isolates tested. Reisolation from arbitrarily selected seedlings yielded isolates that were morphologically the same as those used to inoculate the plant. Of those isolates identified $(38 \%)$, the species pathogenic to soybean were Pythium ultimum (16.5\%), P. vexans $(3.8 \%)$, P. aphanidermatum (26.6\%), P. irregulare $(2.5 \%)$, and group HS $(35.4 \%)$. In addition, $P$. oligandrum made up $15.2 \%$ of the identified isolates and was not pathogenic. Of the remaining isolates not identified, $26 \%$ produced hyphal sporangia and were avirulent or weakly aggressive.

\section{DISCUSSION}

Flooding affected many of the plant parameters measured. Plant stands were less than for the nonflooded controls after flooding at emergence, but not at V4. Plant weights were reduced by flooding, and these reductions were significant two out of the 3 years for flooding at emergence and one out of 3 years for flooding at V4. The plant parameter that changed the most consistently with flooding was root discoloration. Flooding at either emergence or V4 resulted in significant increases in root discoloration compared with the nonflooded treatments. Even though genotypes differed in root discoloration in nonflooded treatments, all genotypes had a similar root discoloration response to flooding.

These results are similar to previous reports for flood damage to soybean. Russell et al. (20) observed that seedlings had difficulty surviving as little as $48 \mathrm{~h}$ of flooding, which is similar to stand loss that resulted from flooding at emergence (3day duration) in these studies. Flooding also has been reported to decrease plant dry weight, with loss in dry weight being greater after a 14-day flood than a 2-day flood (22).

Root discoloration associated with flooding could be the result of the anaerobic soil environment, colonization by soilborne plant pathogens, or both. In our study, we were not able to separate the effect of flooding from disease, but disease symptoms caused by soilborne plant pathogens have been reported to increase with flooding (3-5,12,19,28-30). A number of pathogens were recovered from soybean roots in this study. Some of the pathogens were recovered less frequently with flooding, such as $M$. phaseolina and Fusarium spp. These fungi may have been in the roots, but were sloughed off with parts of the roots during flooding, thus reducing their recovery. Recovery of $R$. solani was not consistently affected by flooding, and occurred at a low percentage. A few nonsoybean pathogens were also recovered, such as binucleate Rhizoctonia spp. and G. graminis. These fungi may be parasitic or opportunistic saprophytes on soybeans. In all years, soybean followed rice in rotation. G. graminis var. graminis is a known rice pathogen causing crown sheath rot.

The only group of plant pathogens whose frequency of recovery was in- creased with flooding was Pythium spp. These increases were significant one of the 3 years for flooding at emergence and all 3 years for flooding at V4. Almost half of the isolates tested were pathogenic to soybean. Identification of those isolates revealed species known to be pathogenic to soybean, Pythium ultimum, $P$. aphanidermatum, $P$. irregulare, and group HS. P. vexans has not been reported to be a pathogen of soybean previously (31). In a later study, all of these species, including $P$. vexans, were shown to be pathogenic to soybean, but their aggressiveness was temperature dependent (17). Besides the pathogenic species, $P$. oligandrum, which is a reported hyperparasite (24), was isolated. Populations of Pythium have been reported to increase rapidly when water is available after irrigation (10), which can result in increased disease caused by Pythium spp. under flooded conditions $(3-5,12)$. In this study, the pathogenic Pythium spp. recov-

Table 5. Analysis of variance $P$ values for the effects of flooding at emergence or the $\mathrm{V} 4^{\mathrm{a}}$ growth stage and host genotype ${ }^{\mathrm{b}}$ on recovery of Macrophomina phaseolina (Mac), Pythium spp. (Pyt), and Fusarium spp. (Fus) from soybean roots over 3 years

\begin{tabular}{lrccc}
\hline Source of variation & df & Mac & Pyt & Fus \\
\hline Flooded at emergence & & & & \\
$\quad$ Year & 2 & 0.0235 & 0.1130 & 0.0001 \\
Flood & 1 & 0.1779 & 0.2027 & 0.4002 \\
Flood $\times$ year & 2 & 0.5762 & 0.0239 & 0.0393 \\
Genotype & 5 & 0.3682 & 0.2432 & 0.2053 \\
Genotype $\times$ year & 10 & 0.0199 & 0.2788 & 0.5634 \\
Flood $\times$ genotype & 5 & 0.6463 & 0.7988 & 0.9029 \\
Flood $\times$ genotype $\times$ year & 10 & 0.7089 & 0.8996 & 0.6827 \\
Flooded at V4 & & & & \\
Year & 2 & 0.0221 & 0.8863 & 0.0090 \\
Flood & 1 & 0.0697 & 0.1094 & 0.4176 \\
Flood $\times$ year & 2 & 0.0172 & 0.0014 & 0.0441 \\
Genotype & 5 & 0.1340 & 0.7076 & 0.6117 \\
Genotype $\times$ year & 10 & 0.5402 & 0.5668 & 0.7391 \\
Flood $\times$ genotype & 5 & 0.2758 & 0.5915 & 0.1036 \\
Flood $\times$ genotype $\times$ year & 10 & 0.2063 & 0.3292 & 0.1601 \\
\hline
\end{tabular}

${ }^{a}$ Plots were flooded for 3 days when the plants were emerging or for 7 days when the plants reached the fourth leaf node growth stage (V4) (8).

${ }^{\mathrm{b}}$ Fifteen plants per plot of the cultivars Hartz 5164, Crowley, Asgrow 4715, NK S59-60, RVS-499, and TB881266 were sampled 4 days (1996) or 3 days (1997 and 1998) after removal of the flood and the roots were assayed for filamentous eukaryotic organisms.

Table 6. Effect of flooding at soybean emergence or V4a growth stage on recovery (\%) of Macrophomina phaseolina, Pythium spp., and Fusarium spp. from soybean roots of six genotypes ${ }^{\mathrm{b}}$ sampled over 3 years

\begin{tabular}{|c|c|c|c|c|c|c|c|c|c|}
\hline \multirow[b]{2}{*}{ Flood } & \multicolumn{3}{|c|}{ M. phaseolina } & \multicolumn{3}{|c|}{ Pythium spp. } & \multicolumn{3}{|c|}{ Fusarium spp. } \\
\hline & 1996 & 1997 & 1998 & 1996 & 1997 & 1998 & 1996 & 1997 & 1998 \\
\hline No flood & 4.5 & 8.9 & 11.5 & 10.9 & 16.7 & 9.3 & 7.4 & 67.0 & 84.4 \\
\hline Emergence & 3.0 & 3.0 & 10.0 & 20.9 & 27.3 & 55.3 & 10.4 & 62.4 & 53.9 \\
\hline $\operatorname{LSD}^{\mathrm{c}}$ & & ns & & & 18.5 & & & 17.8 & \\
\hline $\mathrm{LSD}^{\mathrm{d}}$ & & ns & & & 20.7 & & & 20.0 & \\
\hline No flood & 56.5 & 54.0 & 34.8 & 8.1 & 22.3 & 10.0 & 51.7 & 49.4 & 71.5 \\
\hline V4 & 29.9 & 24.8 & 24.8 & 42.8 & 31.1 & 45.9 & 37.4 & 56.7 & 56.7 \\
\hline $\mathrm{LSD}^{\mathrm{c}}$ & & 8.9 & & & 8.1 & & & 12.9 & \\
\hline $\operatorname{LSD}^{\mathrm{d}}$ & & 10.6 & & & 14.4 & & & 13.5 & \\
\hline
\end{tabular}

${ }^{\text {a }}$ Plots were flooded for 3 days when the plants were emerging or for 7 days when the plants reached the four leaf growth stage (V4) (8).

${ }^{b}$ Fifteen plants per plot of the cultivars Hartz 5164, Crowley, Asgrow 4715, NK S59-60, RVS-499, and TB881266 were sampled 4 days (1996) or 3 days (1997 and 1998) after removal of the flood and the roots were assayed for filamentous eukaryotic organisms.

${ }^{\mathrm{c}}$ Least significant differences (LSD) to compare flood treatments within a year $(P=0.05)$.

${ }^{\mathrm{d}} \mathrm{LSD}$ to compare flood treatments among years $(P=0.05)$. 
ered have been reported to be active over a wide range of temperatures $(17,23,24)$. For example, $P$. ultimum is active below $20^{\circ} \mathrm{C}$, while $P$. aphanidermatum is most active at 30 to $35^{\circ} \mathrm{C}(23,24)$. This wide range in temperature optima among these species implies that one or more species of $P y$ thium could affect soybeans throughout the season.

While soybean can compensate for early season stand loss through the remainder of the growing season by the plant canopy filling in the row (6), seedling diseases may still affect yield. Flooding at either emergence or V4 resulted in significant yield losses compared with nonflooded soybeans, even though significant stand loss occurred only following flooding at emergence (unpublished data). It may be that chronic disease of soybeans caused by Pythium spp. can last throughout the season by slowing recovery of the plant after flooding and reducing growth and vigor of the plants.

One way of reducing yield loss due to flooding is with flood tolerant genotypes. Unfortunately, previous flood tolerance designations were not confirmed in this study. However, there was some indication of flood tolerance with the genotype N92195 in 1996, which had significantly lower root discoloration than all other genotypes for the flood at emergence treatment. N92195 also had the greatest plant stand among the genotypes in the flooded treatment (unpublished data). Another example was the genotype Archer, which in 1998 had a significantly greater plant stand than other genotypes even though the flood that year was especially severe (unpublished data). Some of the other genotypes had complete stand loss due to flooding at emergence in 1998. While these findings are not conclusive, they indicate that there may be flood-tolerant genotypes. Identifying these genotypes, and determining the role of Pythium spp. in flood damage, could greatly improve the techniques to screen for flood tolerance and reduce yield losses due to flooding.

\section{ACKNOWLEDGMENTS}

This research was supported in part by grants from the United Soybean Board. We thank E. E. Gbur for his assistance in statistical analyses.

\section{LITERATURE CITED}

1. Barta, A. L. 1985. Metabolic response of Medicago sativa L. and Lotus corniculatus L. roots to anoxia. Plant Cell Environ. 9:127-131.

2. Bennett, J. M., and Albrecht, S. L. 1984. Drought and flooding effects on $\mathrm{N}_{2}$ fixation, water relations, and diffusive resistance of soybean. Agron. J. 76:735-740.

3. Biesbrock, J. A., and Hendrix, F. F. 1970. Influence of continuous and periodic soil water conditions on root necrosis of holly caused by Pythium spp. Can. J. Bot. 48:1641-1645.

4. Biesbrock, J. A., and Hendrix, F. F. 1970. Influence of soil water and temperature on root necrosis of peach caused by Pythium spp. Phytopathology 60:880-882.

5. Brown, G. E., and Kennedy, B. W. 1966. Effect of oxygen on Pythium seed rot of soybean. Phytopathology 56:407-411.

6. Caviness, C. E. 1961. Effects of skips in soybean rows. Arkansas Agric. Exp. Stn. Arkansas Farm Research 10, 12.

7. Chirkova, T. V. 1978. Some regulatory mechanisms of plant adaptation to temporal anaerobiosis. Pages 137-154 in: Plant Life in Anaerobic Environments. Ann Arbor Science, Ann Arbor, MI.

8. Fehr, W. R., Caviness, C. E., Burmood, D. T., and Pennington, J. S. 1971. Stage of development descriptions for soybeans, Glycine max (L.). Merr. Crop Sci. 11:929-931.

9. Gronewald, J. W., and Hanson, J. B. 1982. Adenine nucleotide content of corn roots as affected by injury and subsequent washing. Plant Physiol. 69:1252-1256.

10. Hancock, J. G. 1977. Factors affecting soil populations of Pythium ultimum (a widespread soil-borne pathogen in temperate climates, causing preemergence and postemergence damping-off and root necrosis in a great number of ornamental and crop plants) in the San Joaquin Valley of California. Hilgardia 45(4):107-122.

11. Heatherly, L. G., and Pringle, H. C. 1991. Soybean cultivars response to flood irrigation of clay soil. Agron. J. 83:231-236.

12. Kerr, A. 1964. The influence of soil moisture on infection of peas by Pythium ultimum. Aust. J. Biol. Sci. 17:676-685.

13. Killebrew, J. F., Roy, K. W., and Abney, T. S. 1993. Fusaria and other fungi on soybean seedlings and roots of older plants and interrelationships amoung fungi, symptoms, and soil characteristics. Can. J. Plant Pathol. 15:139-146.

14. Little, T. M., and Hills, F. J. 1972. Statistical Methods in Agricultural Research. University of California, Davis.

15. Morris, P. F., and Ward, E. B. 1992. Chemoattraction of zoospores of the soybean pathogen Phytophthora sojae by isoflavones. Physiol. Mol. Plant Pathol. 40:17-22.

16. Mozafar, A., Gamperle, R., and Loch, J. 1992. Root aeration inhibits the recovery of soybean from flooding-induced chlorosis under non calcareous conditions. J. Plant Nut. 15:1927-1937.
17. Nanayakkara, R. 2001. Influence of soybean cultivar, seed quality, and temperature on seed exudation and Pythium disease development. $\mathrm{Ph} . \mathrm{D}$. thesis. University of Arkansas, Fayetteville.

18. Oosterhuis, D. M., Scott, H. D., Hampton, R. E., and Wullschleger, S. D. 1990. Physiological responses of two soybean cultivars to shortterm flooding. Environ. Exp. Bot. 30:85-92.

19. Rao, B., Schmitthenner, A. F., Caldwell, R., and Ellett, C. W. 1978. Prevalence and virulence of Pythium species associated with root rot of corn in poorly drained soil. Phytopathology 68:1557-1563.

20. Russell, D. A., Wong, D. L., and Sachs, M. M. 1990. The anaerobic response of soybean. Plant Physiol. 92:401-407.

21. Schmitthenner, A. F. 1985. Problems and progress in control of Phytophthora root rot of soybean. Plant Dis. 69:362-368.

22. Scott, H. D., DeAngulo, J., Daniels, M. B., and Wood, L. S. 1989. Flood duration effects on soybean growth and yield. Agron. J. 81:631636.

23. Thomson, T. B., Athow, K. L., and Laviolette, F. A. 1971. The effect of temperature on the pathogenicity of Pythium aphanidermatun, $P$. debaryanum, and P. ultimum on soybean. Phytopathology 61:933-935.

24. Van der Plaats-Niterink, A. J. 1981. Monograph of the genus Pythium. Studies in Mycology No. 21. Centraalbureau Voor Schimmelculutres, Baarn, the Netherlands.

25. VanToai, T. T., Beuerlein, J. E., Schmitthenner, A. F., and St. Martin, S. K. 1994. Genetic variability for flooding tolerance in soybeans. Crop Sci. 34:1112-1115.

26. Waterhouse, G. M. 1967. Key to Pythium Pringsheim. Mycological Paper No. 109 Commonwealth Mycological Institute, Kew, Surrey, England. pp. 1-15.

27. Wetterauer, D. G., and Killorn, R. J. 1996 Fallow- and flooded-soil syndromes: Effects on crop production. J. Prod. Agric. 9:39-41.

28. Wilcox, W. F., and Mircetich, S. M. 1985. Effect of flooding duration on the development of Phytophthora root and crown rots of cherry. Phytopathology 75:1451-1455.

29. Wilcox, W. F., and Mircetich, S. M. 1985. Influence of soil water matric potential on the development of Phytophthora root and crown rots of Mahaleb Cherry. Phytopathology 75:648-653.

30. Yanar, Y., Lipps, P. E., and Deep, I. W. 1997. Effect of soil saturation duration and soil water content on root rot of maize caused by $P y$ thium arrhenomanes. Plant Dis. 81:475-480.

31. Yang, X. B. 1999. Pythium damping-off and root rot. Pages 42-44 in: Compendium of Soybean Diseases. G. L. Hartman, J. B. Sinclair, and J. C. Rupe, eds. American Phytopathological Society, St. Paul, MN.

32. Yang, X. B. 1994. Fusarium root rot and soybean Rhizoctonia root rot. Iowa State University, Cooperative Extension Service, Ames. 